\title{
Solar Tracker in P.T.U E.P Department
}

\author{
Dr. Zarchi San1, Daw Pan Wint Hmone Htwe1, Daw Kkhaing Wint ${ }^{2}$
}

\author{
${ }^{1}$ Lecturer, ${ }^{2}$ Assistant Lecturer \\ 1,2Department of Electrical Power Engineering, Ministry of Education, \\ 1,2Pyay Technological University (P.T.U), Pyay, Myanmar
}

\begin{abstract}
How to cite this paper: Dr. Zarchi San | Daw Pan Wint Hmone Htwe | Daw Kkhaing Wint "Solar Tracker in P.T.U E.P Department" Published in International Journal of Trend in Scientific Research and Development (ijtsrd), ISSN: 24566470, Volume-3 I Issue-3, April 2019, pp.1619-1623, URL: https://www.ijtsrd.c om/papers/ijtsrd23 468.pdf

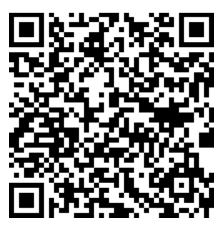
IITSRD23468
\end{abstract}

Copyright (C) 2019 by author(s) and International Journal of Trend in Scientific Research and Development Journal. This is an Open Access article distributed under the terms of the Creative Commons

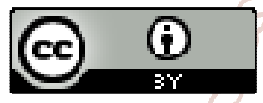
Attribution License (CC BY 4.0) (http://creativecommons.org/licenses/ by $/ 4.0$ )

\section{INTRODUCTION}

Solar power in Myanmar has the potential to generate $51,973.8 \mathrm{TWh} /$ year, with an average of over 5 sun hours per day. The country aims to generate $8 \%$ of electricity through renewable energy sources-through wind and solar energy - by 2021 and $12 \%$ by 2025 . The weather is hottest from March-May among twelve months in Myanmar.

The following solar energy technologies can be successfully propagated: solar cookers; solar water heating systems for industrial application; solar distillation units for battery charging; solar photovoltaic systems for water pumping, battery charging, and power supply to children's hospitals for operating vital equipment. Solar air driers can be used for agricultural and industrial products.

Since Myanmar is a land of plentiful sunshine, especially in central and southern regions of the country, the first form of energy- solar energy could hopefully become the final solution to its energy supply problem. The direct conversion of solar energy into electricity using photovoltaic system has been receiving intensive installation not only in developed countries but also in developing countries.

It is mainly intended to present solar energy potential and application in Myanmar. It is also wanted to get the benefits of using solar energy for people in remote areas which are not yet connected to the national grids because of the high price of fossil fuel.
MEPE (Myanma Electric Power Enterprise) experimental measurements indicate that irradiation intensity of more than $5 \mathrm{kWh} / \mathrm{m}^{2} /$ day was observed during the dry season.

If solar panel is installed in fixed position, solar power can absorb when the sun faces with solar panel. Even single axis moves, the efficiency of solar power can prove by comparing with dual axis as sun orbit is changing all the year.

The overall block diagram for solar tracker in P.T.U E.P Department is shown in figure 1. After light dependence resistors had sensed where the sun is, the motors can move the solar panel due to Ardunio program. The battery either can store energy from solar during sunny days or can give supply when the rainy or cloudy days. The maximum $360 \mathrm{~W}$ loads such as laptop and projector can draw from solar tracker through inverter.

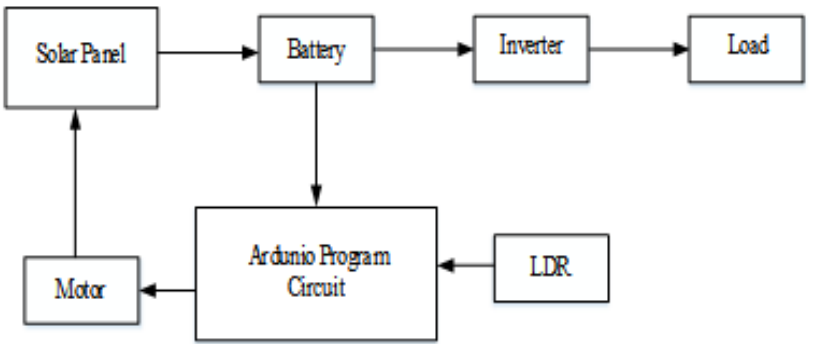

Figure1. The overall block diagram for solar tracker in P.T.U E.P Department 


\section{A. Solar Panel of Project}

Since an individual cell produces only about $0.5 \mathrm{~V}$, it is a rare application for which just a single cell is of any use. Instead, the basic building block for PV applications is a module consisting of a number of pre-wired cells in series, all encased in tough, weather-resistant packages. When photovoltaics are wired in series, they all carry the same current, and at any given current their voltage add as shown in Figure2. There are 36 cells in one PV panel to produce 18 $\mathrm{V}$ because one cell has $0.5 \mathrm{~V}$.

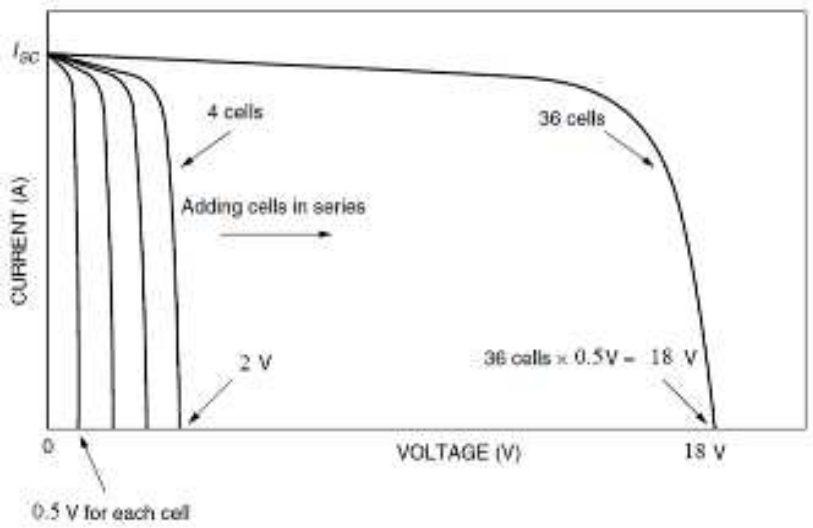

Figure2. For cells wired in series, this module will have 36 cells

By substituting equation 1, 2 and 3, the voltage and current of $90 \mathrm{~W}$ solar panel can be calculated assuming $\mathrm{R}_{\mathrm{p}}>1 \Omega$ and $\mathrm{R}_{\mathrm{s}}<0.005 \Omega$.

$$
\mathrm{I}=\mathrm{I}_{\mathrm{sc}}-\mathrm{I}_{0}\left(\mathrm{e}^{38.9 \mathrm{~V}_{\mathrm{d}}}-1\right)-\frac{\mathrm{V}_{\mathrm{d}}}{\mathrm{R}_{\mathrm{p}}}
$$

$\mathrm{I}_{\mathrm{SC}} \quad=$ short-circuit current,

$\mathrm{I}_{0} \quad=$ the reverse saturation current $(\mathrm{A})$,

$\mathrm{V}_{\mathrm{d}} \quad=$ voltage across the diode terminals

$\mathrm{R}_{\mathrm{P}} \quad=$ parallel resistance,

$\mathrm{V}_{\text {module }}=\mathrm{n}\left(\mathrm{V}_{\mathrm{d}}-\mathrm{I} \mathrm{R}_{\mathrm{s}}\right)$

$\mathrm{R}_{\mathrm{S}} \quad=$ series resistance,

$\mathrm{P} \quad=\mathrm{V}_{\text {module }} \times \mathrm{I}$

Researc Average temperature $\left({ }^{\circ} \mathrm{C}\right)$ and Daily Solar Radiation Develop Horizontal $\left(\mathrm{kWh} / \mathrm{m}^{2} / \mathrm{d}\right)$ of Pyay are expressed in Table 2. Even in cold season, power is nearly about 76W. As April is hot season, solar radiation is the most among other months.

Table2. Average temperature $\left({ }^{\circ} \mathrm{C}\right)$ and Daily Solar Radiation Horizontal $\left(\mathrm{kWh} / \mathrm{m}^{2} / \mathrm{d}\right)$ of Pyay

\begin{tabular}{|c|c|c|}
\hline Month & $\begin{array}{c}\text { Average } \\
\text { Temperature } \\
\left({ }^{\circ} \mathrm{C}\right)\end{array}$ & $\begin{array}{c}\text { Daily Solar Radiation } \\
\text { Horizontal } \\
\left(\mathrm{kWh} / \mathrm{m}^{2} / \mathrm{d}\right)\end{array}$ \\
\hline January & 23.5 & 5.26 \\
\hline February & 25.5 & 5.90 \\
\hline March & 29.3 & 6.44 \\
\hline April & 31.8 & 6.60 \\
\hline May & 30.9 & 5.31 \\
\hline June & 28.2 & 3.78 \\
\hline July & 27.4 & 3.82 \\
\hline August & 27.6 & 3.73 \\
\hline September & 28 & 4.36 \\
\hline October & 27.9 & 4.59 \\
\hline November & 26 & 4.64 \\
\hline December & 23.5 & 4.88 \\
\hline
\end{tabular}

\section{Sun Path of Pyay}

The sun's position can be described by its altitude angle $\beta$ and its azimuth angle $\varphi_{S}$. Altitude angle and azimuth angle is drawn in Figure 4. parallel to increase current. In Figure 3, four solar module are connected in parallel so the current total value also reach nearly $20 \mathrm{~A}$.
Modules can be wired in series to increase voltage, and in
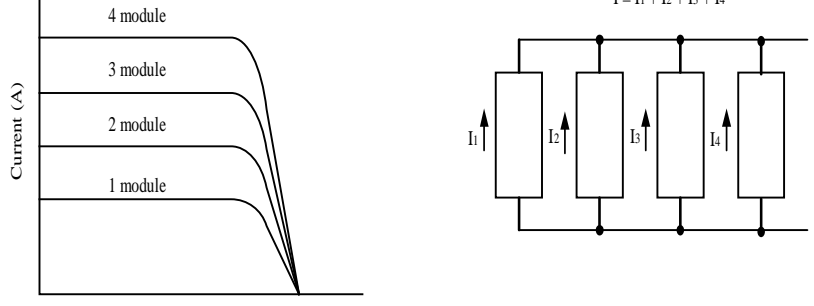

Figure3. For modules in parallel, voltage is the same but current will increase

\section{B. Temperature and Solar Radiation in Pyay}

Annual solar radiation of Pyay is $4.94 \mathrm{kWh} / \mathrm{m}^{2} / \mathrm{d}$. At an average temperature of $31.8^{\circ} \mathrm{C}$, April is the hottest month of the year. January is the coldest month, with temperatures veraging $23.5^{\circ} \mathrm{C}$.

$$
\mathrm{T}_{\text {cell }}=\mathrm{T}_{\mathrm{amb}}+\left(\frac{\mathrm{NOCT}-20^{\circ}}{0.8}\right) \mathrm{S}
$$

$\mathrm{T}_{\text {cell }}=$ cell temperature $(\mathrm{C})$

NOCT = nominal operating cell temperature $(\mathrm{C})$

From Equation 4, after cell temperature can get. As $\mathrm{V}_{\mathrm{OC}}$ drops by $0.37 \% / \mathrm{C}$ and maximum power expected to drop about $0.5 \%$ / C, it is about $16 \%$ drop of rated power.

By combing many cells, one module becomes. The electrical specification for $90 \mathrm{~W}$ solar panel is expressed in Table 1.

Table1. The electrical specification of Solar panel

\begin{tabular}{|c|c|}
\hline Maximum power, Pmax & $90 \mathrm{~W}$ \\
\hline Maximum voltage, Vmp & $18 \mathrm{~V}$ \\
\hline Maximum current, Imp & $4.99 \mathrm{~A}$ \\
\hline Open circuit voltage, Voc & $22.3 \mathrm{~V}$ \\
\hline Short circuit current, Isc & $5.34 \mathrm{~A}$ \\
\hline
\end{tabular}




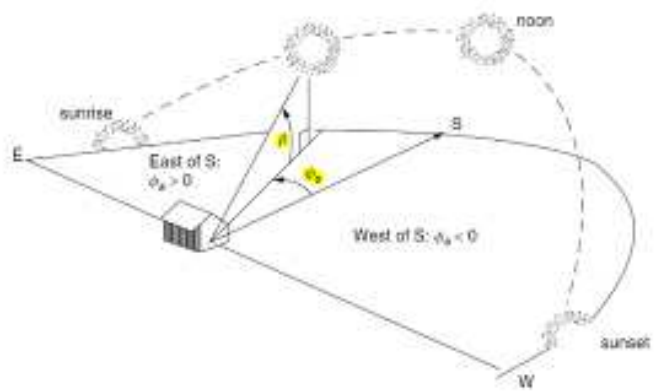

Figure4. The sun's position can be described by its altitude angle $\beta$ and its azimuth angle $\varphi_{S}$.

$\sin \beta=\cos L \cos \delta \cos H+\sin L \sin \delta$

$\beta=$ altitude angle of the sun

$\delta=$ solar declination

$\mathrm{L}=$ the latitude of the site

$\mathrm{H}=$ hour angle

$\sin \varphi_{\mathrm{s}}=\frac{\cos \delta \sin \mathrm{H}}{\cos \beta}$

$\varphi_{S}=$ azimuth angle

By substituting Latitude of Pyay in Equation 5 and 6, sun path of Pyay can be calculated.

\section{Dual Axis Tracking System}

Dual axis tracking system can move Eastand West and North and South as not same as single axis. Total power $360 \mathrm{~W}$ can produce by connecting parallel four $90 \mathrm{~W}$ solar panel. This Figure can be seen in Figure 5. The length and width of one $90 \mathrm{~W}$ panel is 4 ( 4 Feet) and $21^{\prime \prime}(21$ Inches) so total measurement is 7 ( 7 Feet) and 4 (4 Feet).

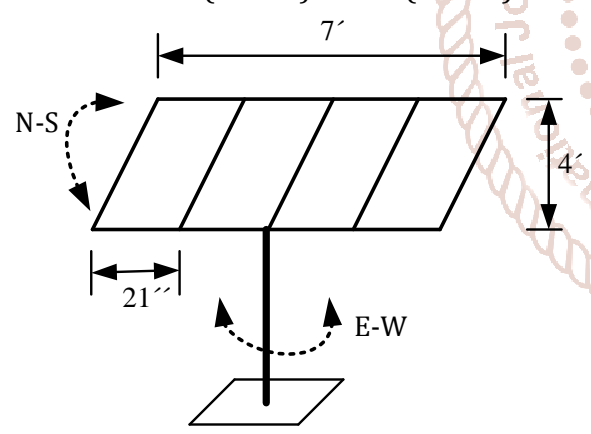

Figure5. Dual Axis Solar Panel in P.T.U E.P Department

Moreover, dual axis tracking system is more efficient than single axis tracking system. Trackers are described as being either two-axis trackers, which track the sun both in azimuth and altitude angles so the collectors are always pointing directly at the sun, or single-axis trackers, which track only one angle or the other. It can be proved that by using the following Equations.

Two-Axis Tracking

$\mathrm{I}_{\mathrm{BC}}=\mathrm{I}_{\mathrm{B}}$

$\mathrm{I}_{\mathrm{BC}}=$ beam insolation on collector

$\mathrm{I}_{\mathrm{B}}=$ beam insolation at earth's surface

$\mathrm{I}_{\mathrm{DC}}=\mathrm{CI}_{\mathrm{B}}\left[\frac{1+\cos \left(90^{\circ}-\beta\right)}{2}\right]$

$\mathrm{I}_{\mathrm{DC}}=$ diffuse insolation on collector

$\beta=$ solar altitude angle

One-Axis

$\mathrm{I}_{\mathrm{BC}}=\mathrm{I}_{\mathrm{B}} \cos \delta$
$\mathrm{I}_{\mathrm{DC}}=\mathrm{CI}_{\mathrm{B}}\left[\frac{1+\cos \left(90^{\circ}-\beta+\delta\right)}{2}\right.$

Total rate at which radiation strikes a collector $I_{C}$ can be gotten by summing beam insolation $\mathrm{I}_{\mathrm{B}}$ and diffuse insolation on collector $I_{D C} I_{C}$ of two axis tracking is $1015 \mathrm{~W} / \mathrm{m}^{2}$ and $I_{C}$ of one axis is $928 \mathrm{~W} / \mathrm{m}^{2}$ by substituting above equation $7,8,9$ and 10 . Therefore, dual axis is $9 \%$ higher than the single-axis mount.

\section{E. Ardunio Program}

To rotate dual axis, Ardunio program is applied in this paper. There are four pins for output and four sensors for East, West, South and North. There are two motors for moving. We need to command the circuit the following program. int $\mathrm{k}=80 ; / /$ tolerance

void setup 0

\{

pinMode(2,OUTPUT);

pinMode(3,OUTPUT);

pinMode(4,OUTPUT);

pinMode(5,OUTPUT);

\} void loop0

\{

int val1=analogRead(A0);//Sensor1 for East int val2=analogRead(A1);//Sensor2 for West int val3=analogRead(A2);//Sensor3 for South int val4=analogRead(A3);//Sensor4 for North int Ref=analogRead(A4);//Reference Voltage if(val1 $>$ (val2+k)\&\&val1 $<$ Ref\&\&val $<<$ Ref) \{ digitalWrite(2,HIGH);//motor1 for Forward digitalWrite(3,LOW); \} if ((val1 $>$ val2\&\&val1 $<$ (val2+k) \&\&val $1<$ Ref \&\&val2 $<$ Ref $) \mid$ (val $2>$ val1\&\&val2<(val1+k)\&\&val1<Ref\&\&val2<Ref)

\{ digitalWrite(2,LOW);//motor1 for Stop digitalWrite(3,LOW);

\}

if $(($ val $2>$ (val1+k) \&\&val2<Ref\&\&val $1<$ Ref $)$

$\|$ (val1>=Ref\&\&val2>=Ref))

\{

digitalWrite(2,LOW);

digitalWrite(3,HIGH);

\} if(val3>(val4+k)\&\&val3<Ref\&\&val4<Ref)

\{ digitalWrite(4,HIGH); digitalWrite(5,LOW); \} 


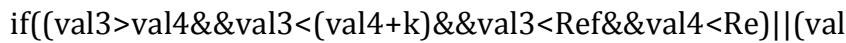
$4>$ val3 $\& \&$ val $4<($ val3 $+\mathrm{k}) \& \&$ val3 $<$ Ref $\& \&$ val $4<$ Ref $)$ )

\{

digitalWrite(4,LOW);

digitalWrite(5,LOW);

\}

if ((val4>(val3+k)\&\&val4<Ref\&\&val3<Ref) $\mid$ (val3>=Ref\&\&val $4>=$ Ref))

\{

digitalWrite(4,LOW);

digitalWrite(5,HIGH);

\}

\}

\section{Result}

Finally, we can choose the battery and inverter rating for loads and solar panel. Solar panel is four $90 \mathrm{~W}$ and its voltage and current are $18 \mathrm{~V}$ and $20 \mathrm{~A}$. The more energy can be stored in the $12 \mathrm{~V}, 120 \mathrm{Ah}$ battery by tracking solar panel and its charging time is $6 \mathrm{hr}$. This DC voltage can change to $\mathrm{AC}$ voltage through inverter. The rating of inverter is $500 \mathrm{~W}$ and $40 \mathrm{~A}$ fuse rating is chosen. The main aim of this project is that to use the laptop and projector in the Department of Electrical Power in Pyay Technological University when the light is off. The power of laptop and projector are $60 \mathrm{~W}$ plus $282 \mathrm{~W}$. So, the total load is about $342 \mathrm{~W}$ that is reliable with solar.These ratings are inserted in Table.

Table3. The Ratings of Overall the Project

\begin{tabular}{|c|c|}
\hline Components & Specification \\
\hline Solar Panel & $\begin{array}{l}90 \mathrm{~W}, 5 \mathrm{~A}, 4 \text { panel parallel } \\
360 \mathrm{~W}, 20 \mathrm{~A}, 18 \mathrm{~V}\end{array}$ \\
\hline Battery & $\begin{array}{l}\text { Choose } 12 \mathrm{~V}, 120 \mathrm{Ah} \text { Battery } \\
20 \mathrm{~A}, 6 \mathrm{hr} \text { charging }\end{array}$ \\
\hline Inverter & $\begin{array}{l}360 \mathrm{~W} \times 0.2 \text { (safety margin) }=72 \mathrm{~W} \\
360 \mathrm{~W}+72 \mathrm{~W}=432 \mathrm{~W} \\
\text { Choose } 500 \mathrm{~W}, 12 \mathrm{~V} \sim 230 \mathrm{~V} \\
500 \mathrm{~W} / 12 \mathrm{~V}=41 \mathrm{~A} \\
40 \mathrm{~A} \text { fuse }\end{array}$ \\
\hline Load & $\begin{array}{l}\text { Laptop14-15in }=60 \mathrm{~W} \\
\text { Projector EPSON EBW05 }=282 \mathrm{~W} \\
\text { Total }=342 \mathrm{~W}\end{array}$ \\
\hline
\end{tabular}

To rotate solar panel, we require the altitude and azimuth angles. The result of these angles is drawn with Matlab program in Figure 6.

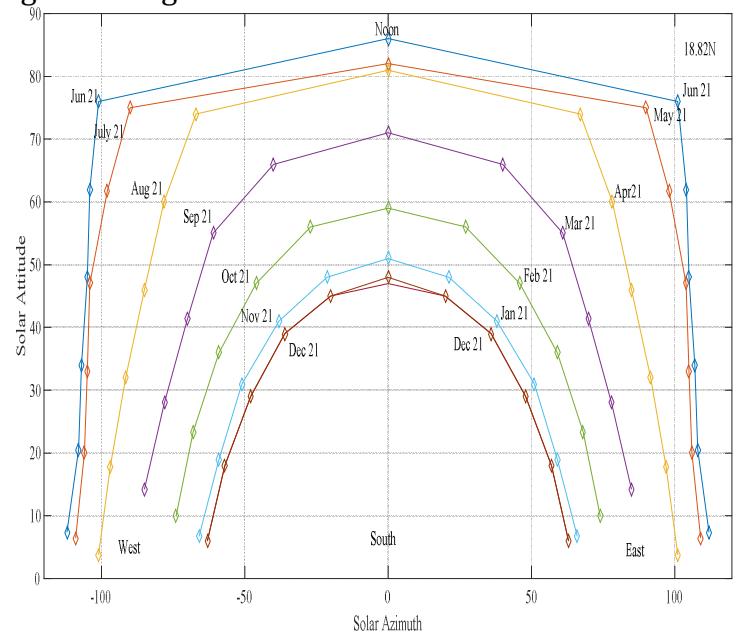

Figure6. Sun Path Diagram Showing Azimuth and Altitude Angles for $18.82^{\circ}$ Latitude (at Pyay)
An inverter is an electronic device or circuitry that changes direct current (DC) to alternating current (AC). The square wave inverter is one of the simplest waveforms among others such as pure sine wave inverter, modified sine wave inverter and is best suited to low-sensitivity applications such as lighting and heating. To supply AC load, inverter is required and Figure 7 is simulation result of square wave output of inverter. The straight line with blue color is DC 12 $\mathrm{V}$ and the square wave with red color is for output $230 \mathrm{~V}$. Square wave is used when the electricity has a constant force, such as it has with DC but switches direction more or less instantly at the same kind of frequency as the normal grid supply (at 50 times per second).

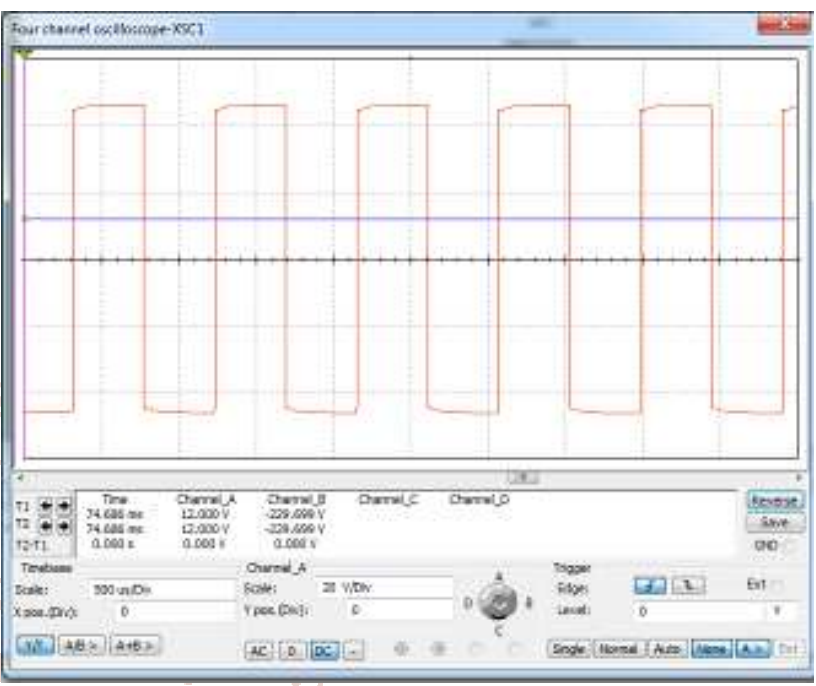

Figure7. Simulation Result of Square Wave Output of Inverter

\section{Recommendations}

As this solar tracker is only functional, we have many plans to continue this project. We can draw this circuit in Proteus software. We can substitute DC motor with stepper motor to be very definite by giving PIC program. The stepper motor can move step by step very detail. We can add charge controller circuit and the circuit to overcome for battery overcharging. Moreover, we can collect more data with measuring instruments with time schedule such as daily, monthly and yearly. We should consider how much cost effective and energy efficiency by comparing $360 \mathrm{~W}$ fixed solar panel and equal power dual axis.

\section{Conclusion}

In Myanmar, renewable energy especially solar power is applied in many villages without connecting National Grid. But, they are mostly installed in fixed position. Dual axis solar tracker is very less when comparing fixed position. This project is very useful because we can give presentation even there is no electricity or the light is off. As four $90 \mathrm{~W}$ solar panel are connected in parallel, laptop and projector can cover from this $360 \mathrm{~W}$ solar panel. Pyay can get the efficient solar radiation so solar power is very suitable in this place.

\section{Acknowledgement}

Our Energy and Machine Research group also acknowledges Dr. Nyunt Soe, Rector, Pyay Technological University. Our group also likes to express special thanks to Dr. Soe Winn, Professor, Head of Electrical Power Engineering, Pyay Technological University. Our research group would like to 
say thanks to everyone who help us to do many researches directly or indirectly. Finally and specially, our heartfelt thanks to our parents, family, our pupils, friends and colleagues. Without getting the help from our students from Pyay Technological University, we cannot do any research.

\section{References}

[1] Ahmed F.Zobaa and Ramesh C.Bansal: Handbook of Renewable Energy Technology, 2011

[2] Gilbert M. Master, ISBN 0-471-28060-7): Renewable and Efficient Electric Power System

[3] Google Search
[4] H.P.Garg and J.Prakash, Solar Energy Fundamentals and Application, New Delhi: Tata MC Graw - Hill, 2005, pp7

[5] Moh Moh Lwin : Master Thesis :Design and Implementation of Photovoltaic Solar Powered Water Pumping System in Hngetpyittaung Village

[6] Swe Swe Mar : Master Thesis: Performance Analysis of Dual-Axis Solar Tracking System using DC Motor

[7] Solar Energy Potential and Applications in Myanmar, Thet Thet Han Yee, Su Su Win, and Nyein Nyein Soe

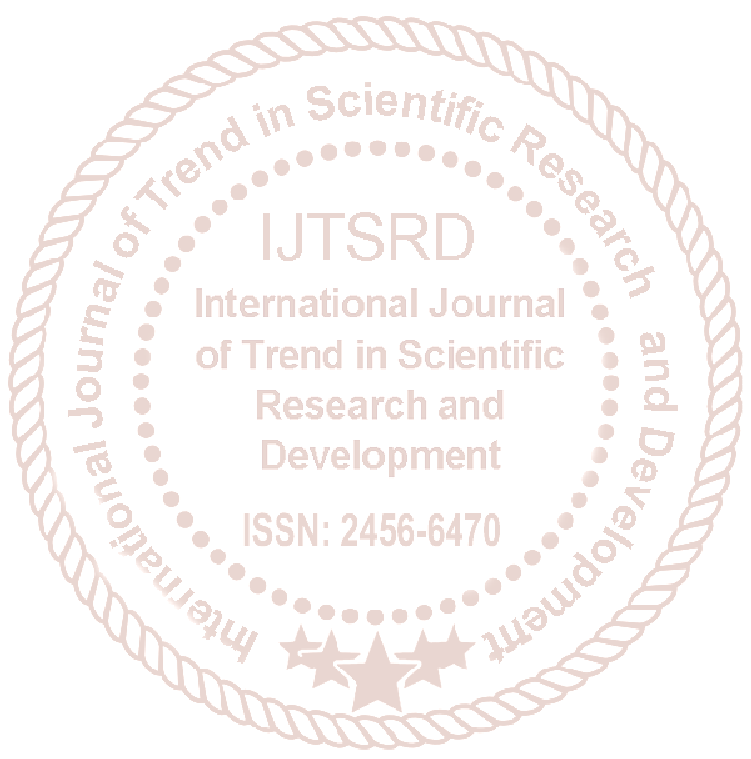

